\title{
Stuck between Health and Immigration Reform - Care for Undocumented Immigrants
}

\section{Citation}

Sommers, Benjamin D. 2013. "Stuck Between Health and Immigration Reform - Care for Undocumented Immigrants." N Engl J Med 369 (7) (August 15): 593-595. doi:10.1056/ nejmp1306636.

\section{Published Version}

doi:10.1056/NEJMp1306636

\section{Permanent link}

http://nrs.harvard.edu/urn-3:HUL.InstRepos:14008381

\section{Terms of Use}

This article was downloaded from Harvard University's DASH repository, and is made available under the terms and conditions applicable to Other Posted Material, as set forth at http:// nrs.harvard.edu/urn-3:HUL.InstRepos:dash.current.terms-of-use\#LAA

\section{Share Your Story}

The Harvard community has made this article openly available.

Please share how this access benefits you. Submit a story.

\section{Accessibility}



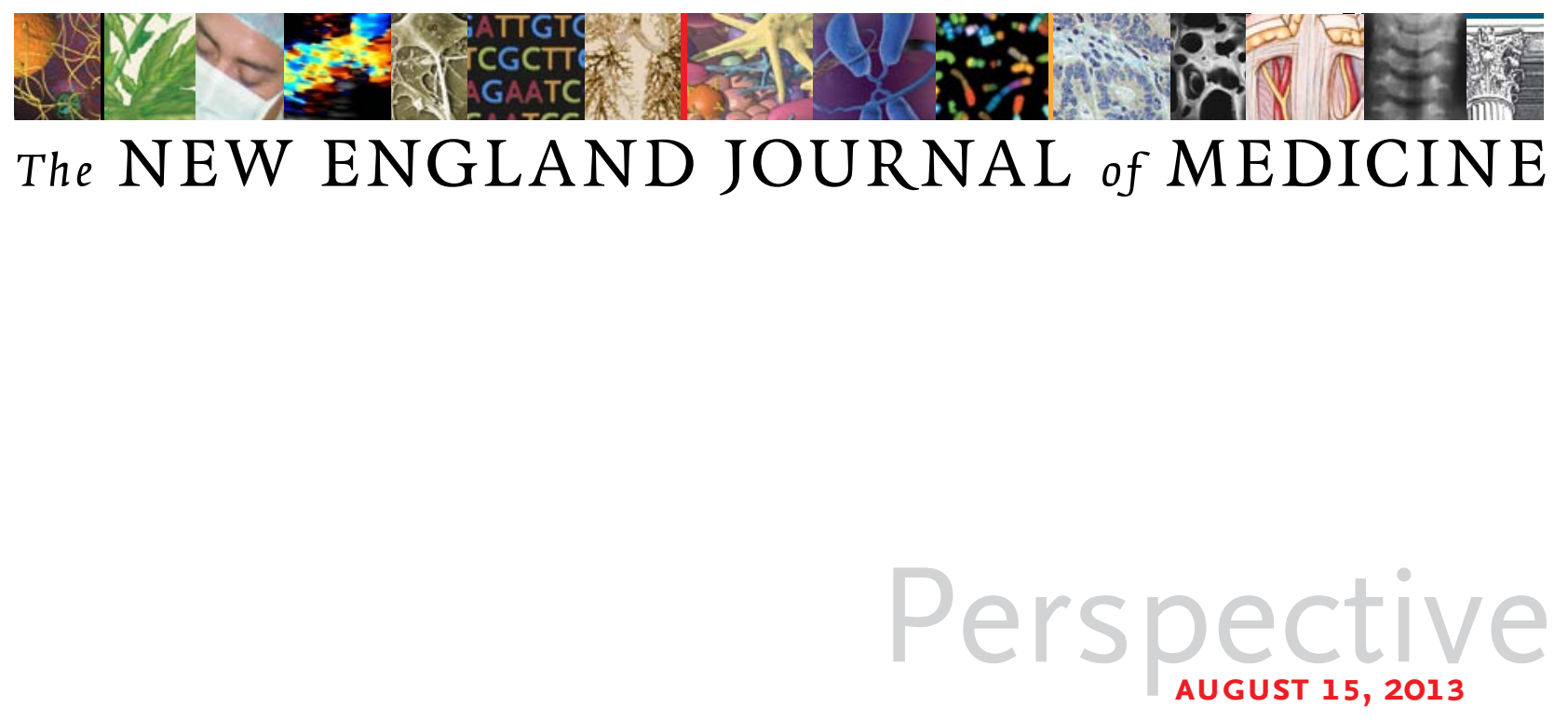

\title{
Stuck between Health and Immigration Reform - Care for Undocumented Immigrants
}

\author{
Benjamin D. Sommers, M.D., Ph.D.
}

\section{T $t$ is a time of immense change in U.S. health care and immigration policy. On the cusp of major insurance expansions under the Affordable Care Act (ACA), Congress is now debating a path to citizenship}

for millions of undocumented immigrants. Understanding what will (and won't) change under the ACA and immigration reform is critical to crafting sensible health policy in this realm. Despite a flurry of political activity, health care for undocumented immigrants remains a patchwork with gaping holes, and that reality is unlikely to change much over the coming decade.

Approximately 25 million noncitizens live in the United States, 11 million to 12 million of them undocumented. Though more than $75 \%$ of undocumented residents are Latin American, U.S. immigrants are more diverse than generally recognized, with sub- stantial numbers from South and East Asia, Europe, Canada, and Africa. ${ }^{1}$ Regardless of its origins, this population's health care options remain limited.

For most undocumented immigrants, the primary sources of U.S. health insurance are unavailable. Although approximately $80 \%$ of adult undocumented immigrants are in the labor force, most are in low-income fields that rarely offer health insurance, such as farming, building maintenance, and food preparation. ${ }^{1}$ Meanwhile, undocumented immigrants are expressly excluded from Medicaid, the primary coverage option for many low-income citizens, and un- documented elderly adults are ineligible for Medicare. The only federal health program available to some undocumented immigrants is Emergency Medicaid, which covers acute care in inpatient settings and emergency departments for persons who, aside from their immigration status, meet their state's Medicaid-eligibility criteria. Given the small numbers of people who are eligible and the limited scope of services covered, Emergency Medicaid does little to facilitate meaningful access to care for most immigrants.

The cumulative effects of these systematic limitations on insurance for undocumented immigrants, combined with low household incomes, are major disparities in health care access between this population - particularly Latino immigrants - and U.S. citizens. Whereas approximately $15 \%$ of 
the overall U.S. population lacks health insurance, nearly two thirds of undocumented Latino immigrants are uninsured. Less than $60 \%$ of undocumented Latinos report having a regular medical provider, and they receive recommended preventive care at far lower rates than citizens. ${ }^{2}$ When they arrive in this country, most immigrants are healthier than the U.S.-born population - the so-called immigrant paradox but within one or two generations, they have become on average less healthy than nonimmigrants, probably because of the adoption of unhealthy American lifestyles combined with systematic access disparities that prevent appropriate care for this population's growing burden of chronic diseases. ${ }^{3}$

One underrecognized aspect of the exclusion of undocumented immigrants from the health care system is the adverse effect on millions of U.S. citizens (disproportionately children) who live in households with undocumentedimmigrant relatives. Research suggests that immigration law enforcement produces a "chilling effect" on Medicaid participation by eligible citizens who live with noncitizen family members. ${ }^{4}$

What options for care do undocumented immigrants have? Some state and local governments spend resources to provide health insurance to persons in need, regardless of their immigration status. As detailed in the Perspective article by Parmet, however, state or locally funded programs even when focused on legal immigrants - are politically precarious and typically first on the chopping block during economic downturns.

For many undocumented immigrants, Federally Qualified Health Centers (FQHCs) are one of the only options for care. Supported by federal grants from the Health Resources and Services Administration and favorable payment policies under Medicaid, FQHCs are required to provide both urgent and preventive care to all comers, regardless of immigration status or ability to pay. These centers, which include designated migrant health centers, treat approximately 20 million people in the United States and serve as an important locus of culturally competent care for immigrant communities.

But there are not enough community health centers to serve the entire population. In the gap, public health programs provide some services to immigrants (such as Title $\mathrm{X}$ for family planning), but these programs are narrowly targeted and administered by states and localities that are often subject to intense immigration-related politics. Thus, many undocumented immigrants - like uninsured persons born in the United States - must rely on charity care from private practitioners and safety-net hospitals, paying out of pocket for costly services, or waiting until their conditions are severe enough to warrant going to the emergency department.

The ultimate backstop - sometimes misleadingly used to assert that no one in the United States goes without needed medical care - is the Emergency Medical Treatment and Active Labor Act (EMTALA). EMTALA requires hospitals to provide care to anyone with an "emergency medical condition" regardless of immigration status or ability to pay. But it contains no requirement to treat life-threatening conditions that are not "emergent" or to treat complications after patients have been stabilized, and it doesn't prohibit billing for those services. Although EMTALA pre- vents hospitals from literally allowing people to die on their doorsteps, it provides neither financial protection nor comprehensive access to care.

U.S. health care will change dramatically in 2014, with insurance expansions under the ACA that will make a major contribution toward coverage for millions of legal immigrants. But both Medicaid and tax credits for coverage through health insurance exchanges will remain off limits for undocumented immigrants, even for beneficiaries of the so-called Dream Act, who were brought here as children and, in 2012, given a reprieve by President Barack Obama from the threat of deportation. Most undocumented immigrants will remain uninsured, and this group will account for a growing proportion - as much as $25 \%$ - of all uninsured people in the United States after implementation of the ACA. ${ }^{5}$

Though excluded from the law's key changes, undocumented immigrants will be affected by other provisions. More will qualify for the limited benefits of Emergency Medicaid, though that change may not occur in several states with large numbers of undocumented immigrants - including Texas and Florida - if they choose not to expand Medicaid under the ACA (see map). The law increases direct funding to FQHCs by $\$ 11$ billion over 5 years, which will benefit many immigrants, but this increase will be traded off against cuts in disproportionate-sharehospital (DSH) payments, putting additional strain on safety-net hospitals caring for undocumented immigrants. Meanwhile, public support for local programs that treat uninsured people (who are disproportionately undocumented) may diminish, as resources are diverted into ACA-related coverage 


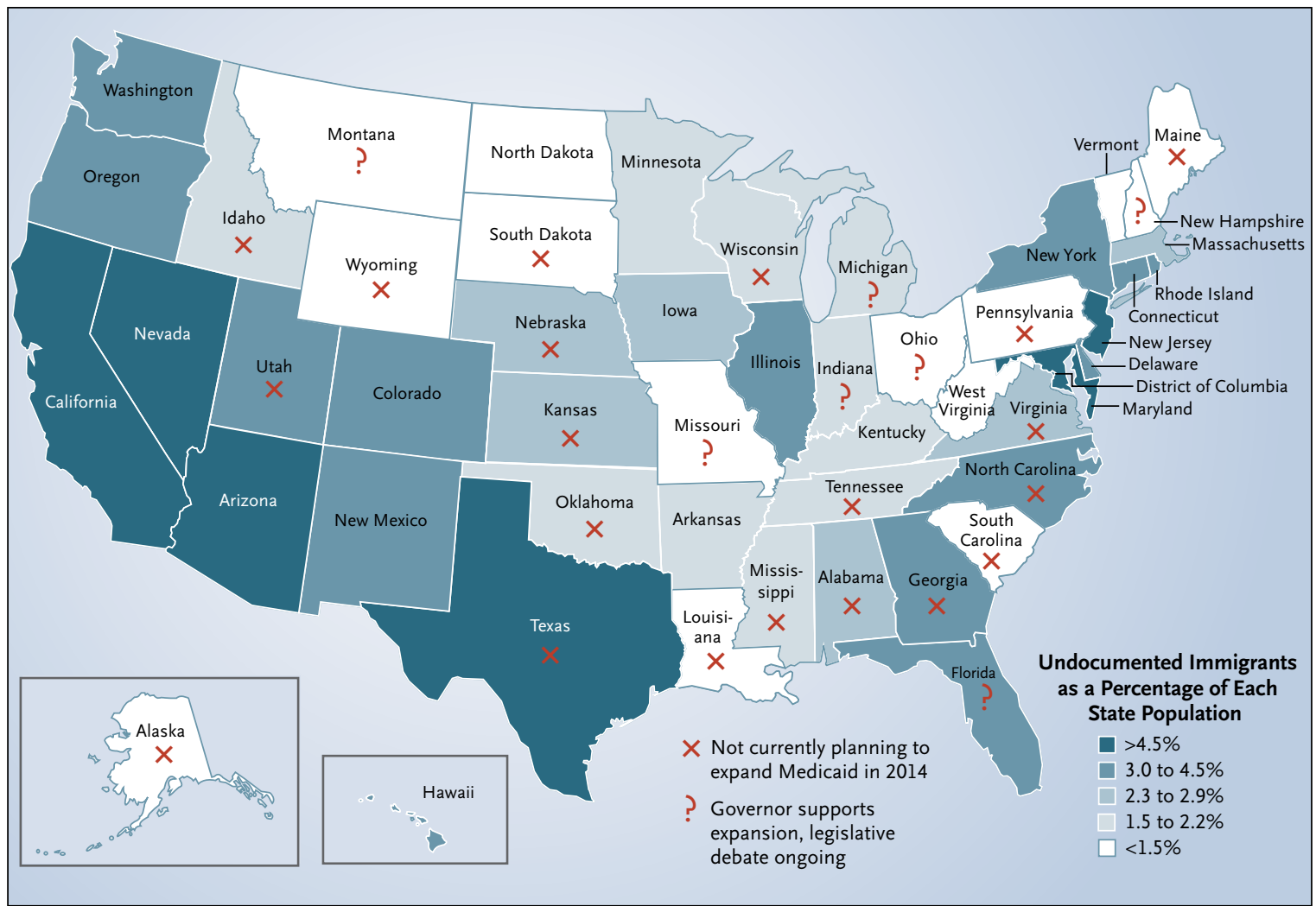

Undocumented Immigrants as a Percentage of Each State Population and Current Medicaid Expansion Plans.

Data on undocumented immigrants as a percentage of each state population in 2010 are from Passel and Cohn (www.pewhispanic .org/files/reports/133.pdf). Information on current state Medicaid-expansion plans comes from the Kaiser Family Foundation and local news reports. States without red symbols are planning to expand Medicaid.

- paradoxically making access to care for this population potentially even worse than it is now.

Any long-term solution to disparities in care for undocumented immigrants will require fundamental immigration reform. More specifically, granting undocumented immigrants legal status and a path to citizenship should open the doors to programs such as Medicaid, Medicare, and tax credits for purchasing coverage through exchanges (programs for which some immigrants already pay taxes, even though they don't benefit from them). Current immigration proposals in Congress, however, wouldn't allow such immigrants to obtain citizenship for a decade or more, and health care may be one stumbling block to political compromise.
Although there are valid perspectives on multiple sides of the immigration debate, there are stark public health implications of continuing to permit the existence of a medical underclass comprising more than 10 million people. Neither the recent national health reform law nor the immigration bill currently being considered solves these vexing problems; indeed, these policies may increase the barriers for some undocumented immigrants. For the foreseeable future, undocumented immigrants will remain on the outskirts of our public programs and safety net, a controversial reminder of ongoing inequities in our health care system.

Disclosure forms provided by the author are available with the full text of this article at NEJM.org.
From the Department of Health Policy and Management, Harvard School of Public Health, Boston.

This article was published on July 24,2013 , at NEJM.org.

1. Passel JS, Cohn D. A portrait of unauthorized immigrants in the United States. Washington, DC: Pew Hispanic Center, 2009.

2. Rodríguez MA, Bustamante AV, Ang A. Perceived quality of care, receipt of preventive care, and usual source of health care among undocumented and other Latinos. J Gen Intern Med 2009;24:Suppl 3:508-13.

3. Tavernise $S$. The health toll of immigration. New York Times. May 19, 2013:Al.

4. Sommers BD, Tomasi MR, Swartz K, Epstein AM. Reasons for the wide variation in Medicaid participation rates among states hold lessons for coverage expansion in 2014. Health Aff (Millwood) 2012;31:909-19. [Errata, Health Aff (Millwood) 2012;31:1650, 2831.]

5. Buettgens M, Hall MA. Who will be uninsured after health insurance reform? Princeton, NJ: Robert Wood Johnson Foundation, 2011.

DOI: 10.1056/NEJMp1306636

Copyright (C) 2013 Massachusetts Medical Society. 